\title{
Evaluation of the awareness of childhood cancers by general practitioners, family physicians and pediatricians
}

\author{
Mehtap EZEL CELAKIL ${ }^{1}$ (D), Su Gulsun BERRAK ${ }^{1}$ \\ ${ }^{1}$ Division of Pediatric Hematology and Oncology, Department of Child Health and Pediatrics, School of Medicine, Marmara University, Pendik
Training and Research Hospital, Pendik, Turkey
} Corresponding Author: Mehtap EZEL CELAKIL

E-mail: mehtapcelakil@yahoo.com

Submitted: 07.04.2020 Accepted: 27.06.2020

\section{ABSTRACT}

Objective: Although, childhood cancer was considered as a deadly disease in the past, now it is considered as a life-threatening chronic disease if diagnosed early. The present study evaluates how much the symptoms of childhood cancers are recognised by the physicians in Istanbul, Turkey.

Materials and Methods: The objective of the study and the questionnaire form was explained to participants and they were asked whether they would like to take part in the study. The questionnaire composed of two sections: 1 . Investigated the sociodemographic characteristics of the physicians and 2. Investigated the knowledge of the physicians on childhood cancers (leukaemia, solid tumour, common questions). The physicians were given 2 points for every correct answer; wrong answers and answers such as "I have no idea" were scored 0 points. Based on the correct answers given by all participants, the medians for every question group were calculated. The measure of success was 75 percentile, which was calculated for each question group considering these median values.

Results: Examining the percentages of the correct answers to the questions, the best known were the leukaemia questions (74.6\%) and the less known were the solid tumour questions (57.1\%). The physicians younger than 33 years, which was the mean age, gave better answers to the leukaemia questions and the common questions. When the academic titles of participants were grouped as pediatricians and other physicians, the leukaemia, solid tumour, common group and total points showed statistically high significant differences.

Conclusion: Our study has revealed the need of our country for training programs aimed at increasing the awareness of general practitioners working in primary health care institutions, as these institutions are the first reference centers for the pediatric patient population. Childhood cancer awareness must be improved by implementing training programs which in turn will lead to early diagnosis and referral to an appropriate specialist.

Keywords: Childhood cancer, Recognition, Symptom, Diagnosis

\section{INTRODUCTION}

Although, childhood cancer was regarded as fatal disease in the past, today it is accepted as a chronic disease that endangers life if diagnosed early $[1,2]$. Childhood cancer is generally in the lower ranks in differential diagnosis because it is less common than other childhood diseases and its symptoms are generally not specific. Therefore, there are delays in the diagnosis of cancer in childhood $[3,4]$. Considering that the treatment success is higher in children, the importance of early diagnosis and treatment can be better appreciated. The greatest responsibility at this stage is borne by the general practitioners and the pediatricians who first see the patient. The relationship between the start of the symptoms and the diagnosis time has been frequently studied up to now [5]. However, studies on the awareness of cancer symptomatology of pediatricians and especially primary care physicians are very few, almost none.

The present study aims to evaluate the awareness of pediatricians and physicians of other fields, particularly general practitioners, concerning the symptoms and diagnosis of childhood cancers.

\section{MATERIALS and METHOD}

The present study was conducted by the Pediatric Haematology and Oncology Division of the School of Medicine, Marmara

How to cite this article: Ezel Celakil M, Berrak S G. Research on the differences in the recognition of childhood cancers by general practitioners, family physicians and pediatricians. Marmara Med J 2020;33(3):119-127, doi: 10.5472/marumj.815566 
University, Istanbul. The permit necessary to conduct the study was given by the Istanbul Provincial Health Directorate. The study was approved by the Ethical Committee of School of Medicine, Marmara University (Approval number: B.30.2. MAR.0.01.02/AEK/). The objective of the study and the twopage questionnaire form (Annex1) was explained to the family physicians, general practitioners, pediatricians and surgeons who might confront cancer working in all community health centres, state hospitals, training and research hospitals, university hospitals and private hospitals and they were asked whether they wanted to take part in the study. The questionnaire composed of two sections: 1.Investigated the sociodemographic particulars of the physicians participating in the study and 2. Investigated their awareness on childhood cancers (leukaemia, solid tumour, common questions concerning childhood cancers) (Annex 1). A total of 297 physicians participated in the study and completely filled in the questionnaire distributed at their work center. In the questionnaire, the physicians were given 2 points for every correct answer; wrong answers and answers such as "I have no idea" were scored 0 points. Based on the correct answers given by all participants, the medians for every question group were calculated. The measure of success was 75 percentile, which was calculated for each question group considering these median values. Above this value is accepted as successful in all question groups.

\section{Statistical Analysis}

The data were analysed using the program Statistical Package for the Social Sciences (SPSS) for Windows 19. 0. The answers to the first section questions, which investigated the sociodemographic characteristics and the answers to the second section questions were compared using appropriate statistical tests. The MannWhitney $U$ test was used for comparing the parameters that have no normal distribution in quantitative data and the Kruskal Wallis test was used for comparing more than two groups. Significance level in all tests were taken as $\mathrm{P}<0.05$.

\section{RESULTS}

A total of 297 physicians participated in our study. Of these, 148 (49.8\%) were female and 149 (50.2\%) male. Of the participating physicians, $126(42.4 \%)$ were pediatricians, 67 (22.9\%) were general practitioners, $64(21.2 \%)$ were internal medicine physicians, $22(7.7 \%)$ were surgeons and 18 (5.8\%) were family physicians (Table I).

Table I. The number of participants according to academic degree

\begin{tabular}{ll}
\hline & $\mathrm{N}(\%)$ \\
\hline Female/Male & $148(49.8 \%) / 149(50.2 \%)$ \\
\hline Pediatricians & $126(42.4 \%)$ \\
General practitioners & $67(22.9 \%)$ \\
\hline Internal medicine physicians & $64(21.2 \%)$ \\
Pediatric surgeons & $22(7.7 \%)$ \\
Family physicians & $18(5.8 \%)$
\end{tabular}

It was found that $90(30.3 \%)$ participating physicians had cancer in the family history and 140 (47.1\%) of the participating physicians was diagnosed with cancer at least once in the past, 133 (45\%) followed a child with cancer at least once in the past.

In the present study, the first section of the questionnaire included 11 questions on sociodemographic characteristics. The second section of the questionnaire form had 50 questions concerning characteristics of childhood cancers. Of these questions, $18 \%$ were about leukaemia, $48 \%$ were about solid tumours and $34 \%$ were common questions. Examining the percentages of the correct answers to the questions, the best known were the leukaemia questions (74.6\%) and the least known were the solid tumour questions (57.1\%). The number of correct answers for all questions is given in Annex I.

Tables II and III give the rankings of the first 5 questions that were correctly answered most frequently and that incorrectly answered most frequently and the numbers and percentages of correct answers. No statistical difference was observed when comparing total scores with respect to the gender of the participants (Mann-Whitney U test, $\mathrm{p}=0.441$ ).

Table II. The correct answers most frequently given by the participants

\begin{tabular}{|c|c|c|}
\hline Questions & Group & Correct answers $(\mathrm{N})(\%)$ \\
\hline Sudden weight loss may be the first sign of cancer in a child & Leukemia group & $\begin{array}{c}262 \\
(88.2 \%)\end{array}$ \\
\hline Sudden developing weakness - fatigue can be a sign of cancer in a child & Leukemia group & $\begin{array}{c}260 \\
(87.5 \%)\end{array}$ \\
\hline No further investigation is needed in a child with iris hamartoma and axillary freckling & Common group & $\begin{array}{c}256 \\
(86.1 \%)\end{array}$ \\
\hline The only treatment for leukemias in childhood is radiotherapy & Leukemia group & $\begin{array}{c}256 \\
(86.1 \%)\end{array}$ \\
\hline Fever of unknown origin can be a symptom for childhood cancers & Leukemia group & $\begin{array}{c}254 \\
(85.5 \%)\end{array}$ \\
\hline
\end{tabular}


Table III. The incorrect answers most frequently given by the participants

\begin{tabular}{lcc} 
Questions & Group & $\begin{array}{c}\text { Incorrect answers } \\
(\mathbf{N})(\%)\end{array}$ \\
$\begin{array}{l}\text { The first examinations in a child with } \\
\text { abdominal mass are hemogram and } \\
\text { peripheral smear }\end{array}$ & $\begin{array}{c}\text { Common } \\
\text { group }\end{array}$ & $\begin{array}{c}64 \\
(21.5 \%)\end{array}$ \\
$\begin{array}{l}\text { AFP level is significant in a child with a } \\
\text { posterior mediastinum mass }\end{array}$ & $\begin{array}{c}\text { Solid tumor } \\
\text { group }\end{array}$ & 66 \\
$\begin{array}{l}\text { The definitive diagnosis of brain tumors } \\
\text { in childhood is confirmed by cranial MR }\end{array}$ & $\begin{array}{c}\text { Solid tumor } \\
\text { group }\end{array}$ & $\begin{array}{c}(22.2 \%) \\
(30.3 \%)\end{array}$ \\
$\begin{array}{l}\text { The diagnosis of neuroblastoma is } \\
\text { established in children with abdominal } \\
\text { mass, if VMA and HVA levels are high } \\
\text { in urine }\end{array}$ & $\begin{array}{c}\text { Solid tumor } \\
\text { group }\end{array}$ & $\begin{array}{c}108 \\
(36.3 \%)\end{array}$ \\
$\begin{array}{l}\text { Abdominal masses are the most } \\
\text { common manifestation of malignant } \\
\text { tumors in children }\end{array}$ & $\begin{array}{c}\text { Solid tumor } \\
\text { group }\end{array}$ & $(37.7 \%)$ \\
\hline
\end{tabular}

AFP:Alpha-fetoprotein, VMA: Vanillylmandelic acid, HVA: Homovanillic acid

Mean age in the research group was 33.5 $\pm 7.7(23-67)$. Leukaemia points, common question points and total points of the participants with respect to age group showed statistically significant differences (Mann-Whitney $U$ test, $\mathrm{p}=0.033$ ) (Table IV).

Table IV. Comparison of leukemia, solid tumor, common group and total points according to age groups in the study

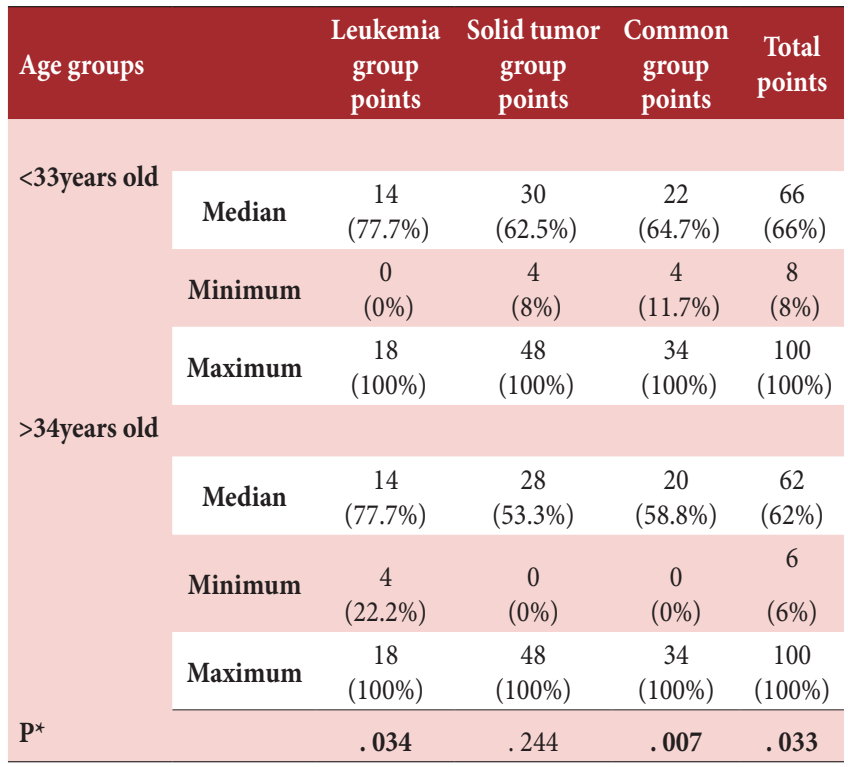

( ${ }^{*}$ Mann-Whitney U test)

The physicians younger than 33 years, which was the mean age, gave better answers to the leukaemia questions and the common questions (Mann-Whitney $U$ test, $p=0.034, p=0.007$ respectively). Although, there was no significant difference between the points for solid tumour questions with respect to age of physicians (Mann-Whitney $U$ test, $\mathrm{p}=0.244$ ), there was significant difference between total scores (Mann-Whitney U test, $\mathrm{p}=0.033$ ) (Table IV). Accordingly, the scores of young physicians were significantly higher. Those physicians who have been practising less than 10 years, were better especially with the common questions (Mann-Whitney U test, $\mathrm{p}=0.006$ ) (Table V).

Table V. Comparison of leukemia, solid tumor, common group and total points according to the duration of occupation of the participants

\begin{tabular}{|c|c|c|c|c|c|}
\hline \multicolumn{2}{|c|}{$\begin{array}{l}\text { Duration of } \\
\text { occupation }\end{array}$} & $\begin{array}{c}\text { Leukemia } \\
\text { group } \\
\text { points }\end{array}$ & $\begin{array}{l}\text { Solid tumor } \\
\text { group points }\end{array}$ & $\begin{array}{c}\text { Common } \\
\text { group } \\
\text { points }\end{array}$ & $\begin{array}{c}\text { Total } \\
\text { points }\end{array}$ \\
\hline \multirow[t]{3}{*}{$<10$ years } & Median & $\begin{array}{c}14 \\
(77.7 \%)\end{array}$ & $\begin{array}{c}28 \\
(58.3 \%)\end{array}$ & $\begin{array}{c}22 \\
(64.7 \%)\end{array}$ & $\begin{array}{c}64 \\
(64 \%)\end{array}$ \\
\hline & Minimum & $\begin{array}{c}0 \\
(0 \%)\end{array}$ & $\begin{array}{c}4 \\
(8 \%)\end{array}$ & $\begin{array}{c}4 \\
(11.7 \%)\end{array}$ & $\begin{array}{c}8 \\
(8 \%)\end{array}$ \\
\hline & Maximum & $\begin{array}{c}18 \\
(100 \%)\end{array}$ & $\begin{array}{c}48 \\
(100 \%)\end{array}$ & $\begin{array}{c}34 \\
(100 \%)\end{array}$ & $\begin{array}{c}100 \\
(100 \%)\end{array}$ \\
\hline \multicolumn{6}{|l|}{$>11$ years } \\
\hline & Median & $\begin{array}{c}14 \\
(77.7 \%)\end{array}$ & $\begin{array}{c}28 \\
(58.3 \%)\end{array}$ & $\begin{array}{c}20 \\
(58.8 \%)\end{array}$ & $\begin{array}{c}60 \\
(60 \%)\end{array}$ \\
\hline & Minimum & $\begin{array}{c}4 \\
(22.2 \%)\end{array}$ & $\begin{array}{c}0 \\
(0 \%)\end{array}$ & $\begin{array}{c}0 \\
(0 \%)\end{array}$ & $\begin{array}{c}6 \\
(6 \%)\end{array}$ \\
\hline & Maximum & $\begin{array}{c}18 \\
(100 \%) \\
\end{array}$ & $\begin{array}{c}48 \\
(100 \%) \\
\end{array}$ & $\begin{array}{c}32 \\
(94 \%) \\
\end{array}$ & $\begin{array}{c}98 \\
(98 \%) \\
\end{array}$ \\
\hline \multicolumn{2}{|l|}{$\mathbf{P}^{*}$} & .131 & .265 & .006 & .041 \\
\hline
\end{tabular}

There were statistically significant differences between the leukaemia, solid tumour, common group and total points with respect to the academic titles of the participants (MannWhitney $\mathrm{U}$ test, $\mathrm{p}=0.0001)$. Accordingly, the best answers in all groups were given by pediatrists and the lowest points were those of the general practitioners. Success limit was accepted as 75th percentile.

Accordingly, $88.8 \%$ of the pediatricians answered the leukaemia questions correctly. Their scores for solid tumour and common group questions were $66.6 \%$ and $64.7 \%$, which were below the success limit. The scores of the physicians in all the other branches were below the success limit. When the academic titles of the participants were grouped as pediatricians and other physicians, the leukaemia, solid tumour, common group and total points showed statistically high significant differences (Mann-Whitney U test, $\mathrm{p}=0.0001$ ) (Table VI). 
Table VI. Comparison of the leukaemia, solid tumour, common group and total points when the academic titles of the participants are grouped as pediatricians and the others

\begin{tabular}{|c|c|c|c|c|c|}
\hline & & $\begin{array}{c}\text { Leukemia } \\
\text { group } \\
\text { points }\end{array}$ & $\begin{array}{l}\text { Solid tumor } \\
\text { group } \\
\text { points }\end{array}$ & $\begin{array}{c}\text { Common } \\
\text { group } \\
\text { points }\end{array}$ & $\begin{array}{c}\text { Total } \\
\text { points }\end{array}$ \\
\hline \multirow[t]{3}{*}{$\begin{array}{l}\text { Other } \\
\text { physicians }\end{array}$} & Median & $\begin{array}{c}12 \\
(66.6 \%)\end{array}$ & $\begin{array}{c}24 \\
(50 \%)\end{array}$ & $\begin{array}{c}20 \\
(58.8 \%)\end{array}$ & $\begin{array}{c}58 \\
(58 \%)\end{array}$ \\
\hline & Minimum & $\begin{array}{c}0 \\
(0 \%)\end{array}$ & $\begin{array}{c}0 \\
(0 \%)\end{array}$ & $\begin{array}{c}0 \\
(0 \%)\end{array}$ & $\begin{array}{c}6 \\
(6 \%)\end{array}$ \\
\hline & Maximum & $\begin{array}{c}18 \\
(100 \%)\end{array}$ & $\begin{array}{c}48 \\
(100 \%)\end{array}$ & $\begin{array}{c}34 \\
(100 \%)\end{array}$ & $\begin{array}{c}100 \\
(100 \%)\end{array}$ \\
\hline \multirow[t]{3}{*}{ Pediatricians } & Median & $\begin{array}{c}16 \\
(88.8 \%)\end{array}$ & $\begin{array}{c}30 \\
(62.5 \%)\end{array}$ & $\begin{array}{c}22 \\
(64.7 \%)\end{array}$ & $\begin{array}{c}68 \\
(68 \%)\end{array}$ \\
\hline & Minimum & $\begin{array}{c}4 \\
(22.2 \%)\end{array}$ & $\begin{array}{c}10 \\
(20.8 \%)\end{array}$ & $\begin{array}{c}8 \\
(23.5 \%)\end{array}$ & $\begin{array}{c}24 \\
(24 \%)\end{array}$ \\
\hline & Maximum & $\begin{array}{c}18 \\
(100 \%) \\
\end{array}$ & $\begin{array}{c}48 \\
(100 \%) \\
\end{array}$ & $\begin{array}{c}34 \\
(100 \%) \\
\end{array}$ & $\begin{array}{c}100 \\
(100 \%) \\
\end{array}$ \\
\hline $\mathbf{P}^{\star}$ & & .000 & .000 & .000 & .000 \\
\hline
\end{tabular}

The physicians whose specialist practice period was between 1-5 years were more successful in answering the leukaemia questions (Kruskal-Wallis test, $\mathrm{p}=0.007$ ) and the common questions (Kruskal-Wallis test, $\mathrm{p}=0.003$ ) than the physicians whose specialist practice period was $>10$ yeas. With respect to total points, there was no significant difference (Kruskal-Wallis test, $\mathrm{p}=0.052$ ). The leukaemia, solid tumour, common group and total points of the participants with respect to having cancer diagnosis in the family and previous cancer follow-up showed statistically significant differences (Mann-Whitney $U$ test, $\mathrm{p}=0.003$ ).

\section{DISCUSSION}

The present study evaluated how much the symptoms of childhood cancers are recognised by the physicians in Istanbul, Turkey. As a result of the study, it was observed that the awareness of especially the general practitioners in Istanbul, Turkey on childhood cancers, primarily the solid tumours, was unsatisfactory. Although, mostly the pediatricians answered the questions correctly, they were not satisfactorily successful except for the leukaemia questions. The best acknowledged questions were the leukaemia questions while the least acknowledged ones were the solid tumour questions. The present study revealed that the knowledge and awareness of general practitioners on childhood cancers must be improved by implementing training programs as they are the first to see a patient.

No study has been conducted in Turkey yet, on how much the childhood cancer symptoms are known by physicians. The studies in the world literature on this subject are few and limited, being only on pediatricians or primary physicians [6-8]. The studies made worldwide and in Turkey on awareness concerning childhood cancer symptoms target cancer patients or the healthy population mostly $[9,10]$. The first study worldwide investigating the awareness of the physicians on childhood cancers was conducted in Brazil in 2007, targeting only general practitioners, with a small number of questions [11]. The mentioned study remained unsatisfactory, especially because the number of the questions asked was few. There were some other studies concerning pediatric oncology that evaluated the time between the start of the cancer symptoms and diagnosis $[12,13]$. One of the few such studies was conducted in Izmir, Turkey in 1997. In the mentioned study, contrary to what had been believed, the shortest diagnosis time was the brain tumours with 54 days, while the longest diagnosis time was Hodgkin's lymphoma with 199 days [13]. The results of the studies made on this subject worldwide are as follows: The time period between onset of symptoms and the confirming diagnosis was found to be on the average 21 days in neuroblastomas and 72 days in Ewing sarcoma conducted in the US in 1991 [14].

In most of the studies, the shortest diagnosis time is in the frequently observed tumours of the infancy, such as neuroblastoma, Wilm's tumour, while the longest diagnosis time is in brain tumours, bone and soft tissue tumours [15]. The two main factors that determine the time between the onset of the symptoms and diagnosis are the patient age and the type of the tumour. Pollock et al., demonstrated in their study that the time between the onset of the symptoms and diagnosis in younger children was shorter but longer in adultery [14]. The most extensive study is a digest published in Canada. According to this digest, the common point for all the studies is that the first reason for delay in the diagnosis of childhood cancers is the physician's delay. This is followed by causes such as delay of the patient and tumour type [16]. In a study conducted in Ghana in 2007, it was demonstrated that the cancers that lead to death most were lymphomas and brain tumours and that the diagnoses of the brain tumour patients who died were in the late stages [17]. This clearly shows the role of the physicians in early diagnosis of childhood cancers. The questions on solid tumours, for which the time between the onset of symptoms and diagnosis was the longest, were the questions which were least correctly answered in our study and the efforts to increase physician awareness concerning this issue are very few, both in Turkey and worldwide.

In a study in Brazil, it was seen that the awareness of the physicians is at a rather low level, not only for brain tumours but for all childhood cancers [11]. Pediatricians and physicians from other branches were included in the present study, while the study in Brazil included only general practitioners but not pediatricians. In the Brazilian study also the least correctly answered questions were the solid tumour questions.

In the current study, there was a significant difference between the awareness for cancer symptoms and sociodemographical characteristics such as the length of specialist practice and age. On the other hand, a significant difference could not be found between the awareness for cancer symptoms and both age and length of practice. No significant relationship could be found between the awareness for cancer symptoms and gender or marital status. The participant physicians who were younger than 33 answered more correctly the leukaemia and common 
questions. The best answered questions in the present study were the leukaemia questions. In leukaemias, 5-year survival is about $85 \%$. This can be related to increased awareness of physicians on leukaemia and early diagnosis of leukaemia.

The knowledge inadequacy of the general practitioners, who were the primary care physicians for pediatric patients in Istanbul, can be clearly seen in the present study. In Turkey, the primary care training programs for childhood cancers, for which the 5-year survival rates are rather high if diagnosed early, are rather inadequate.

One of the main factors related to diagnosis delay is that there are no scan tests for childhood cancers [18]. Despite all these adversaries, early diagnosis in many childhood cancers can be given only by a well taken story and detailed physical examination [1,2]. In a study conducted in Manchester in 2009, more than half of the children with a story of

Li-fraumeni syndrome in the family was found to be positive for TP 53 mutation. The children displayed no syndromes and cancer developed in the follow-up of these children [19]. Similarly, there is the RB gene mutation in the diagnosis of retinoblastoma and there is mutation in the Ret protooncogene in multiple endocrine neoplasia type 1 and 2 (MENI and MEN II). In Turkey, all genetic tests cannot be made due to its high cost.

In the present study, leucocoria, which is one of the diagnostic findings of retinoblastoma, was answered correctly only by $70 \%$ of the participating physicians. This is a rather low rate for retinoblastoma, the 5-year survival rates are about $95 \%$ if diagnosed early. Early diagnosis for lymphoreticular malignities likely to develop may be possible when the existing immune deficiency of the patient at the time of application is assessed together with the family history [20]. Similarly, tendency to malignity increases in some genetic syndromes and syndromes that go together with immune deficiency (increase of the risk of leukaemia in Down syndrome patients, of lymphoreticular malignity and skin cancer risk in Bloom syndrome patients) [21].

It was observed that the physicians of all branches gave wrong answers to the questions on familial cancer syndromes and immune deficiency in our study. Although, the choice of the laboratory tests which will be requested concerning the symptoms at application to the physician is quite meaningful for cancer diagnosis, most of the time they do not provide decisive diagnosis, they can only assist the diagnosis as supporting finding. For a patient suspected of neuroblastoma, high level of neuron specific enolase (NSE) in blood and high level of vanillylmandelic acid (VMA), homovanillic acid (HVA) in urine will be meaningful but not decisive [22,23]. Similarly, although high beta human chorionic gonadotropin (HCG) is important in diagnosis and follow-up of germ-cell tumours, it is not a decisive diagnosis. High alpha fetoprotein (AFP) is also meaningful in the follow-up of germ-cell tumours and hepatocellular cancer [24,25]. In the present study, concerning this issue, the number of correct answers given to question 55, inquiring the relationship between neuroblastoma and levels of
VMA and HVA, was 108 (36\%). As can be seen, the awareness of both general practitioners and paediatricians is pretty low.

The first thing to do to increase physician's awareness in Turkey is to increase epidemiologic studies. As the briefing and training programs for the public and the physicians are rather inadequate in Turkey. In the present study, it was observed that physicians who had, in some way, confronted cancer, who had decided on a cancer diagnosis were more familiar with the symptoms of childhood cancers, without depending on branch, and answered the questions more correctly (Mann-Whitney U test, respectively $\mathrm{p}=0.0001$ ).

In our study, physicians at or above the age 33 were less successful with leukaemia and common questions (Mann-Whitney $U$ test, respectively $\mathrm{p}=0.034, \mathrm{p}=0.007)$. In parallel with this, as the time of practice or the time of specialist practice for specialist physicians increased, the percentages of correct answers given to the questions decreased. That is, as age, time of practice and time of specialist practice increased, the number of wrong answers increased and levels of awareness decreased. Based upon these results, we can say that the trainings after becoming a specialist in Turkey are inadequate. There is no proficiency training program on this issue in Turkey yet. It may be possible to ensure early diagnosis in childhood cancers and provide renewal for physicians by distributing brochures-booklets containing the symptoms of childhood cancers for physicians to health institutions and establishments through the media and the television. Early consultation and information flow can be provided on suspected patients by making such efforts for especially general practitioners. Thus, childhood cancers that might be diagnosed early must not be neglected. Zitzelsberger et al., in a study conducted in 2004, asked family physicians questions on various adult cancers by telephone and e-mail; it was seen that the physicians built up awareness mostly by the internet and the things that could be done concerning this issue was discussed [26]. Another way to diagnose childhood cancers early is to build specific oncology centres for childhood cancers, such as leukaemia center, brain tumour center, solid tumour center. Although, the cost of such an implementation will be high, it will be a good step on the road to early diagnosis. This will ensure directing the patients especially applying to primary care physicians to the correct address. Some awareness trainings on childhood cancers are conducted for the public. The indirect effect of such trainings to increase physician awareness should not be neglected. Even if such efforts aim to raise public awareness in the first place, they will indirectly raise physician's awareness since the application of a conscious individual to the physician, his expectations from the physician and his questions to the physician will be high $[27,28]$. In a study conducted in Amsterdam in 2008, cancer symptoms were asked to the youth; it was demonstrated that the main symptoms, such as blood in the faeces, sudden development of a mass, sudden weight loss, were more effective in consulting a doctor but no importance was given to minor symptoms [29]. There is no study conducted in Turkey on this issue yet. 
In the light of all these data, we can conclude that the trainings in Istanbul, Turkey on this issue, both before and after being a specialist are inadequate.

The present study included a limited number of physician population, representing the Marmara region, Turkey. So, more studies are needed to be done on the awareness of childhood cancers in different regions of Turkey with more participants. Turkey urgently needs training programs to raise the awareness of especially general practitioners working in primary care facilities on childhood cancers. Similar programs should be implemented for pediatricians too since they have remained under the average success level although they have been the group with the highest number of correct answers. Similarly, proficiency programs regarding childhood cancers must be developed for physicians who have not been able to catch up with new advancements as their practice times increase.

\section{Compliance with Ethical Standards}

Ethical Approval: The approval of the ethical board was given by the Ethical Board of the Medicine Faculty of the Marmara University(B.30.2.MAR.0.01.02/AEK/351)

Funding: The authors received no financial support for the study.

Conflict of interest: The authors declare that they have no conflict of interest.

Informed Consent: Informed consent was obtained from all participants.

Authors' Contributions: Concept and Design - MEC,GSB; Resources - MC; Materials - MEC,GSB; Data Collection and Processing - MEC; Analysis and Interpretation - MEC,GSB; Literature Search - MEC,GSB; Writing Manuscript - MEC;

\section{REFERENCES}

[1] Raab CP, Gartner JC Jr. Diagnosis of childhood cancer. Prim Care 2009;36:671-84. doi: 10.1016/j.pop.2009.07.002.

[2] Fragkandrea I, Nixon JA, Panagopoulou P. Signs and symptoms of childhood cancer: a guide for early recognition. Am Fam Physician 2013;88:185-92.

[3] Kutluk T, Yeşilipek A. Pediatrik tümör kayıtları., T.P.O.G.T.P.H. Derneği, Editor. 2007.

[4] Young G, Toretsky JA, Campbell AB, Eskenazi AE. Recognition of common childhood malignancies. Am Fam Physician 2000;61:2144-54. .

[5] Youlden DR, Frazier AL, Gupta S, et al. Stage at diagnosis for childhood solid cancers in Australia: A population-based study. Cancer Epidemiol 2019;59:208-14. doi: 10.1016/j.canep.2019.02.013

[6] Radhi M, Fulbright JM, Ginn KF, Guest EM. Childhood cancer for the primary care physician. Prim Care 2015;42:43-55. doi: 10.1016/j.pop.2014.09.006.

[7] Signorelli C, Wakefield CE, Fardell JE, et al. Anzchog Survivorship Study Group. The role of primary care physicians in childhood cancer survivorship care:
Multiperspective interviews. Oncologist 2018; 31:2018-0103. doi: 10.1634/theoncologist.2018-0103.

[8] Minute M, Cozzi G, Plotti C, et al. Children with cancer: a survey on the experience of Italian primary care pediatricians. Ital J Pediatr 2017;43:48. doi: 10.1186/s13052.017.0365-9.

[9] Bashore L. Childhood and adolescent cancer survivors' knowledge of their disease and effects of treatment. J Pediatr Oncol Nurs 2004;21: 98-102. doi: 10.1177/104.345.4203262754

[10] Moerdler S, Zhang L, Gerasimov E, et al. Physician perspectives on compassionate use in pediatric oncology. Pediatr Blood Cancer 2019;66:e27545. doi: 10.1002/pbc.27545

[11] Workman G, Ribeiro RC, Rai SN, Pedrosa A, Workman DE, Pedrosa F. Pediatric cancer knowledge : assesment of knowledge of warning symptoms for pediatric cancer among Brazilian community health workers. J Cancer Educ 2007; 22:181-5. doi: 10.1007/BF03174334

[12] Fragkandrea I, Nixon JA, Panagopoulou P. Signs and symptoms of childhood cancer: a guide for early recognition. Am Fam Physician 2013;88:185-92.

[13] Aktan G, Cangar Ş, Serdaroğlu E. Pediatrik tümörlerde tanıda gecikme süresi. T Klinikleri Pediatri 1997; 6:97-102.

[14] Pallock H, Krischer J, Teresa J. Interval between symptom onset and diagnosis of pediatric solid tumors. J Pediatr 1991;119:725-32. doi: 10.1016/s0022-3476(05)80287-2

[15] Haimi M, Peretz Nahum M, Weyl Ben Arush M. Delay in diagnosis of children with cancer: A retrospective study of 315 children. Pediatr Hematol Oncol 2004;21:37-48.

[16] Tan TD, Franco EL. Diagnosis delays in childhood cancer. Cancer 2007;110: 703-13. doi: 10.1002/cncr.22849

[17] Gyasi RK, Tettey Y. Childhood deaths from malignant neoplasms in accra. Ghana Med J 2007;41:78-81. doi: 10.4314/ gmj.v41i2.55306.

[18] Korde LA, Gadalla MS. Cancer risk assessment for the primary care physician. Prim Care Clin Office Pract 2009;36: 471-88.

[19] Evans DG, Lunt P, Clancy T, Eeles R. Childhood predictive genetic testing for Li-Fraumeni syndrome. Fam Cancer 2009;9:65-9. doi: 10.1007/s10689.009.9245-9

[20] Plon S. Childhood cancer and heredity. 5th ed. Principles and Practise of Pediatric Oncology, ed. P. Pizzo and D. Poplack. 2006, Philadelphia: Lippincott Williams and Wilkins. 2006:1437.

[21] Apak H. Çocukluk çağı lösemileri. Türk Pediatri Arşivi 2006; 41: $189-96$

[22] Forgie S, Robinson J. Pediatric malignancies presenting as a possible infectious disease. BMC Infect Dis 2007;7:44. doi: 10.1186/1471-2334-7-44

[23] Park J L, Eggert A, Caron H. Neuroblastoma: biology, prognosis, and treatment. Hematol Oncol Clin N Am 2010;24:65-86. doi: 10.1016/j.hoc.2009.11.011

[24] Perkins G, Slater ED, Sanders GK. Serum tumor markers. Am Fam Physician 2003;68: 1075-82.

[25] Yaris N, Mandiracioglu A, Büyükpamukcu M. Childhood cancer in developing countries. Pediatr Hematol Oncol 2004;21:237-53. doi: 10.1080/088.800.10490276971 
[26] Zitzelsberger L, Grunfeld E, Graham LD. Physicians' perspectives on practice guidelines related to cancer control. BMC Fam Pract 2004;5:25. doi: 10.1186/1471-2296-5-25

[27] Nathan PC, Daugherty CK, Wroblewski KE, et al. Family physician preferences and knowledge gaps regarding the care of adolescent and young adult survivors of childhood cancer. J Cancer Surviv 2013;7:275-82. doi: 10.1007/s11764.013.0271-0.
[28] Lawrence RA, McLoone JK, Wakefield CE, Cohn RJ. Primary care physicians' perspectives of their role in cancer care: A systematic review. J Gen Intern Med 2016;31:1222-36. doi: 10.1007/s11606.016.3746-7.

[29] Ruiter RA, De Nooijer J, Van Breukelen G, OckhuysenVermey CF, de Vries H. Intended coping responses to cancer symptoms in healty adults: The roles of symptom knowledge, detection behaviour, and perceived threat. Cancer Epidemiol Biomarkers Prev 2008;17:818-26. doi: 10.1158/1055-9965. EPI-07-0015 


\section{ANNEX 1}

\section{MARMARA UNIVERSITY, SCHOOL OF MEDICINE, DEPARTMENT OF CHILD HEALTH AND PEDIATRICS}

\section{SECTION 1: SOCIODEMOGRAPHIC CHARACTERISTICS}

1. Gender : Female $\quad$ Male $\square$

2. Age:

\section{Marital Status: married $\square$ single $\square$}

4. How long have you been practicing medical profession?

5. Academic title:

Pediatric Specialist $\square$ Internal Medicine specialist $\square$
General Practitioner $\square$

Pediatric Surgery Specialist $\square$

6. How many years have you been working as a specialist? $1-5$ years $\square \quad 5-10$ years $\square \quad>10$ years $\square$

7. Do you have any family member with cancer? Yes $\square \quad$ Nor

8. Have you ever diagnosed with childhood cancer? Yes $\quad$ No $\square$

9. If yes which type of cancer? Leukemia-lymphoma $\square \quad$ Solid tumor $\square \quad$ Brain tumor $\square$

10. Have you ever followed-up a child with cancer? Yes $\square$ No $\square$

11 .If yes which type of cancer? Leukemia-lymphoma $\square$ Solid tumor $\square \quad$ Brain tumor $\square$

\section{SECTION 2: QUESTIONS on CHILDHOOD CANCER}

12. Sudden developing weakness - fatigue can be a sign of cancer in a child

13. Sudden weight loss may be the first sign of cancer in a child

14. Axillary freckling and brown spots in the body do not require further examination if there is no other finding in a child

15. AFP level is significant in a child with a posterior mediastinum mass

16. Prognosis in girls is worse in childhood cancers

17. The definitive diagnosis of brain tumors in childhood is confirmed by cranial MR

18. Back pain can be the first sign of cancer in a child

19. In the physical examination, the palpable abdominal mass is the most common finding of cancer

20. In a child with night sweats, cancer must always be in the differential diagnosis

21. LDH elevation is one of the most significant markers in terms of cancer diagnosis

22. Leukopenia may be the first sign of cancer

23. The most common solid tumor of childhood is a brain tumor

24. Difficulty in urination may be a sign of cancer in a child

25. Childhood cancers are more common in girls

26. Depression may be a sign of cancer in a child

27. Abdominal masses are the most common manifestation of malignant tumors in children 
29. Cancer should be considered in a neonate with a sudden increase in head circumference

30. Evaluation of soft tissue masses in children is not urgent

31. The first differential diagnosis for lymphadenopathy not responding to antibiotic therapy is cancer

32. The most common childhood cancer is CNS tumors

176

33. Each child with cough lasting more than 2 weeks must have a chest X-ray for the diagnosis of a concomitant cancer

35. Radiation therapy should be given to every childhood brain tumor

36. In a child with leukocytosis, the presence of nucleated erythrocytes in peripheral smear may be a sign of cancer

37. Fever of unknown origin can be a symptom for childhood cancer

38. No further investigation is needed in a child with iris hamartoma and axillary freckling

39. The risk of developing cancer in a child with a family history of malignancy at a young age is very high

40. Changes in sudden consciousness may be a sign of cancer in a child

41. The only treatment for leukemias in childhood is radiotherapy

43. A child known to have retinoblastoma in the family should definitely be evaluated for cancer when presented with leg pain 235

44. Toxic granulation in a child with leukocytosis is a symptom of cancer

45. The first examinations in a child with abdominal mass are hemogram and peripheral smear

46. 2 weeks of vomiting accompanied with headaches is the definitive indicator of cancer in children

47 A child with constipation for $>1$ month should have pelvic imaging for cancer

48. Leucocoria is one of the most important signs of cancer in children

49. Unexplained unrest in the newborn may be a sign of cancer

50. Hemogram of leukocytes, erythrocytes, platelet series in the presence of one or more numerical-structural abnormality 252 persists bone marrow aspiration biopsy should be done

51. Retinal pigment hypertrophy should be considered in the eye if there is a family history of familial adenomatosis poliposis 140

52. A child with a history of hearing loss and a family history of brain tumor should be evaluated in terms of familial cancer 240 syndromes

53. Sudden hair loss may be a sign of cancer in the child

54. The most common manifestation of orbital tumors in children is proptosis

55. The diagnosis of neuroblastoma is established in children with abdominal mass, if VMA and HVA levels are high in urine

56. Unexplained bone pain is the definitive symptom of cancer in children

57. All series must be affected to diagnose cancer by looking at the hemogram

58. Stress is one of the most important etiologic causes of cancer in children

59. Children with hemihypertrophy must be followed with abdominal ultrasonography at least 18 years age

60. A child with normal hemogram and peripheral blood smear cannot have leukemia

61. Doctors should be careful in terms of brain tumours in children with headache and a history of skin cancer 